\title{
Biomonitoring of Airborne Heavy Metal Contamination
}

\author{
Mehran Hoodaji, Mitra Ataabadi and Payam Najafi \\ Islamic Azad University, Khorasgan Branch (Isfahan)
}

Iran

\section{Introduction}

During the last few decades, heavy metal contamination of biotic component of environment has attracted the attention of many investigators. The main reason of these researches based on the heavy metal concentration may have a potential hazard in our food chain after a long period of procrastination. Using biological materials in the determination of environmental pollution as indicators is a cheap and reliable method. Various types of plant such as lichens, mosses, bark and leaves of higher plants, have been used to detect the deposition, accumulation and distribution of metal pollution (Akosy, 2008), Because of plants greatly affected by physical and chemical environmental conditions. If conditions become altered, the exposed plant community can accurately reflect these changes (Nash, 1988).

This chapter discusses the possibility of various types of plant usage as biomonitors for detection atmospheric heavy metal pollution in different conditions and factors that affect their accumulative potential.

\subsection{Heavy metals}

Over the past two decades, "heavy metals" has been used increasingly in various publications and in legislation related to chemical hazards and the safe use of chemicals. It is often used as a group name for metals and semimetals (metalloids) that have been associated with contamination and potential toxicity or ecotoxicity (Duffus, 2002).

Now, it is known that heavy metals represent a large group of chemical elements $(>40)$ with atomic mass $>50$ carbon units (Fig 1.) Most of heavy metals may be important trace elements in the nutrition of plants, animals or humans (e.g. $\mathrm{Zn}, \mathrm{Cu}, \mathrm{Mn}, \mathrm{Cr}, \mathrm{Ni}, \mathrm{V}$ ), while others are not known to have positive nutritional effects (e.g. $\mathrm{Pb}, \mathrm{Cd}, \mathrm{Hg}$ ). However all of these may cause toxic effects (some of them at a very low content level) if they occur excessively (Spiegel, 2002). The toxicity of heavy metal depends a great deal on their chemical form, concentration, residence time, etc (Mielke \& Reagan, 1988). Because of these elements do not decay with time, their emission to the environment is a serious problem which is increasing worldwide due to the rapid growth of population, increasing combustion of fossil fuels, and the expansion of industrial activities (Smodis \& Bleise, 2000). 


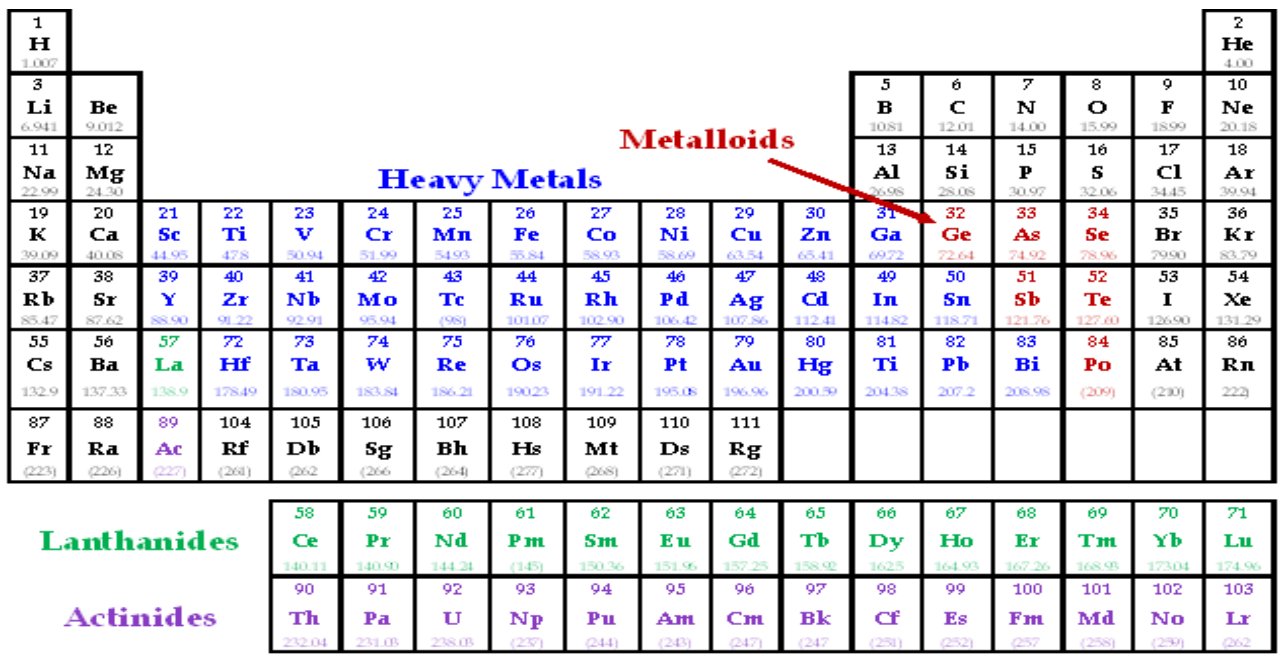

Fig. 1. Heavy metal position in Periodic Table.

\subsubsection{Origin of heavy metals in the environment}

There are two different sources for heavy metals in the environment. These sources can be both of natural or anthropogenic origin.

\subsubsection{Natural}

The principal natural source of heavy metals in the environment is from crustal material that is either weathered on (dissolved) and eroded from (particulate) the Earth's surface or injected into the Earth's atmosphere by volcanic activity. These two sources account for $80 \%$ of all the natural sources; forest fires and biogenic sources, account for $10 \%$ each. Particles released by erosion appear in the atmosphere as windblown dust. In addition, some particles are released by vegetation. The natural emissions of the some heavy metals are 12,000 (Pb); 45,000 (Zn); 1,400 (Cd); 43,000 (Cr); 28,000 (Cu); and 29,000 (Ni) metric tons per year, respectively (Nriagu, 1990).

\subsubsection{Anthropogenic}

There are a multitude of anthropogenic emissions in the environment. Generally heavy metals enter into the environment mainly via three routes: (I) deposition of atmospheric particulates (e.g. Mining, Smelting, Fossil fuel combustion, municipal waste incineration, cement production and phosphate mining). (II) disposal of metal enriched sewage sludge and sewage effluents, commercial Fertilizers and pesticides and animal waste specially to the terrestrial and aquatic environment (III) by-product from metal mining processes (Shrivastav, 2001; Smodis \& Bleise, 2000). Among them, the major source of metals is from mining and smelting. Mining releases metals to the fluvial environment as tailings and to the atmosphere as metal-enriched dust whereas smelting releases metals to the atmosphere as a result of high-temperature refining processes (Adriano, 1986). The estimation of metal input into environment from the two latter sources (II \& III) is relatively easy to measure, but atmospheric input is difficult to quantify accurately because of after emission, the 
pollutants are subjected to physical, chemical and photochemical transformations, which ultimately decide their fate depending upon the atmospheric concentrations (Shrivastav, 2001; Smodis \& Bleise, 2000). Air pollutants do not remain confined near the source of emission, but spread over distances, transcending natural and political boundaries depending upon topography and meteorological conditions, especially wind direction, wind speed and vertical and horizontal thermal gradients (Smodis \& Bleise, 2000). Among the various species present in the particulate matter, a great attention has been devoted since many years to the study of the elements with elevated toxicity and great diffusion in the environment (As, $\mathrm{Cd}, \mathrm{Cr}, \mathrm{Hg}, \mathrm{Ni}, \mathrm{Pb}$, etc.) because of both anthropogenic and natural pollutant emissions (Beijer \& Jernelöv, 1986). The contributions of natural and anthropogenic sources in atmospheric heavy metal pollution are shown in table 1.

\begin{tabular}{|c|c|c|c|c|c|c|c|}
\hline Element & $\begin{array}{l}\text { Fluxes } \\
\text { from } \\
\text { crustal } \\
\text { origin }\end{array}$ & $\begin{array}{l}\text { Fluxes } \\
\text { from } \\
\text { volcanic } \\
\text { origin }\end{array}$ & $\begin{array}{l}\text { Fluxes in } \\
\text { gas of } \\
\text { volcanic } \\
\text { origin }\end{array}$ & $\begin{array}{c}\text { PM } \\
\text { emission of } \\
\text { industrial } \\
\text { origin }\end{array}$ & $\begin{array}{l}\text { Element } \\
\text { flux from } \\
\text { fossil fuel }\end{array}$ & $\begin{array}{c}\text { Total } \\
\text { Emission }\end{array}$ & $\begin{array}{c}\text { Atmospheric } \\
\text { Alteration } \\
\text { Factor }\end{array}$ \\
\hline$\overline{\mathrm{Ag}}$ & 0.5 & 0.1 & 0.0006 & 40 & 16 & 50 & 8333 \\
\hline $\mathrm{Al}$ & 356,500 & 132,750 & 8.4 & 40,000 & 32,000 & 72,000 & 15 \\
\hline As & 25 & 3 & 0.1 & 620 & 160 & 780 & 2786 \\
\hline $\mathrm{Cd}$ & 2.5 & 0.4 & 0.001 & 40 & 15 & 55 & 1897 \\
\hline $\mathrm{Co}$ & 40 & 30 & 0.04 & 24 & 20 & 44 & 63 \\
\hline $\mathrm{Cr}$ & 500 & 84 & 0.005 & 650 & 290 & 940 & 161 \\
\hline $\mathrm{Cu}$ & 100 & 93 & 0.012 & 2200 & 430 & 2630 & 1363 \\
\hline $\mathrm{Fe}$ & 190,000 & 87,750 & 3.7 & 75,000 & 32,000 & 107,000 & 39 \\
\hline $\mathrm{Hg}$ & 0.3 & 0.1 & 0.001 & 50 & 60 & 110 & 27,500 \\
\hline $\mathrm{Mn}$ & 4250 & 1800 & 2.1 & 3000 & 160 & 3160 & 52 \\
\hline Mo & 10 & 1.4 & 0.02 & 100 & 410 & 510 & 4474 \\
\hline $\mathrm{Ni}$ & 200 & 83 & 0.0009 & 600 & 380 & 980 & 348 \\
\hline $\mathrm{Pb}$ & 30 & 8.7 & 0.012 & 16,000 & 4300 & 20,300 & 34583 \\
\hline $\mathrm{Sb}$ & 9.5 & 0.3 & 0.013 & 200 & 180 & 380 & 3878 \\
\hline Se & 3 & 1 & 0.13 & 50 & 90 & 140 & 3390 \\
\hline Sm & 32 & 9 & - & 7 & 5 & 12 & 29 \\
\hline Sn & 50 & 2.4 & 0.005 & 400 & 30 & 430 & 821 \\
\hline $\mathrm{Ti}$ & 23000 & 12,000 & - & 3600 & 1600 & 5200 & 15 \\
\hline V & 500 & 150 & 0.05 & 1000 & 1100 & 2100 & 323 \\
\hline $\mathrm{Zn}$ & 250 & 108 & 0.14 & 7000 & 1400 & 8400 & 2346 \\
\hline
\end{tabular}

Table 1. Natural and anthropogenic element fluxes (value $\times 10^{8} \mathrm{~g} \mathrm{y}^{-1}$ )

Atmospheric Alteration Factor $(\%)=$ Total Emission/ (Fluxes from crustal origin+Fluxes from volcanic origin) $\times 100$ (from Avino et al., 2008).

\subsubsection{Fate and transport of atmospheric heavy metals in the environment}

The environmental and human health effects of heavy metals depend on the mobility of each metal through environmental compartments and the pathways by which metals reach humans and the environment. The free ion is generally the most bioavailable form of a metal, and the free ion concentration if often the best indicator of toxicity. However, there are exceptions, such as the well known case of mercury, where the organic form, (methyl 
mercury) is more toxic than the inorganic ion. Metals exert toxic effects if they enter into biochemical reactions in the organism and typical responses are inhibition of growth, suppression of oxygen consumption and impairment of reproduction and tissue repair (Long et al., 1995). The World Health Organization (WHO) estimates that more than 2 million premature deaths occur annually worldwide, and these can be attributed to the effects of outdoor and indoor air pollution (WHO, 2002). The main outdoor air pollutants are as follows: particulate matter (PM), carbon monoxide, nitrogen oxides, sulfur oxides, ozone, and volatile organic compounds. Most of the mortality/morbidity caused by atmospheric pollution in urban areas is caused by PM with aerodynamic diameters less than $10 \mu \mathrm{m}$, known as the inhalable fraction (MacNee \& Donaldson, 2000). Heavy metals occur, in atmosphere, basically in particulate form. PM-containing heavy metals may induce the oxidative stress mediated by reactive oxygen, with potential mutagenic effects as a strong correlation between the high elemental concentrations in aerosol particles and high mortality and morbidity has been found in several epidemiological studies (Manoli et al., 2002).

\subsubsection{Mechanisms of heavy metal deposition}

The aerosols, which have a very small falling velocity, are easily transferred by the wind and it is possible to be deposited through the rain at long distances from the point of their emission (Smirnioudi et al., 1998). Therefore, it is expected that chemical components in the rainwater (acid components, anions, cations and heavy metals) damage significantly the environment (surface waters, plants, animals, human beings). These metals even if deposited constantly in small rates over long periods of time, accumulate in the environment and will probably pose an increasing major environmental and human health hazard in future.

The transfer of airborne particles to land or water surfaces by dry, wet and occult deposition constitutes the first stage of accumulation of atmospheric heavy metals. The predominant path depends upon the type of chemical species and upon meteorological factors such as the intensity and distribution of rain fall.

\subsection{Dry deposition}

Dry deposition involves four distinct processes: gravitational settling, impaction, turbulent transfer and transfer by Brownian motion. The relative importance of these processes depends primarily on the size of particles (Shrivastav, 2001). Dry deposition is more likely to remove particulate forms. Two major categories of particulate matter are fine particles and coarse particles. Fine particulate matter (FPM) comprises particles with aerodynamic diameters of $2.5 \mu \mathrm{m}$ or less. They are emitted from fossil fuel combustion, motor vehicle exhausts (including diesel) and wood burning. Several toxic metals, including arsenic, cadmium, lead, zinc, antimony and their compounds are associated with FPM in ambient air. This is important from a public health perspective since these fine particles are respirable and can be transported over very long distances. Coarse particulate matter or $\mathrm{PM}_{10}$ is the mass concentration of particulate matter having aerodynamic diameters less than $10 \mu \mathrm{m}$ (USEPA, 1996). Anthropogenically added particulates and aerosols in atmosphere show a broad size distribution from $0.001 \mu \mathrm{m}$ to $50 \mu \mathrm{m}$ and are strongly influenced by atmospheric transport processes. In rural regions anthropogenic particles $>5$ $\mu \mathrm{m}$ are absent (Ward et al., 1975) and in Polar Regions heavy metals are mostly associated with small aggregated particles in the range of 0.1-10 $\mu \mathrm{m}$. Dry deposition of heavy metals in rural and remote regions is therefore, through impaction and turbulent transfer (Barrie \& 
Schemenauer, 1986). Dry deposition represents a major removal pathway for many pollutants from the atmosphere, and it is especially important in arid and semiarid regions where removal by wet deposition (i.e., rainfall scavenging) is greatly diminished because of limited precipitation (Seinfeld \& Pandis 1998).

\subsection{Wet deposition}

In wet deposition, there are always some atmospheric hydrometeors which scavenge aerosol particles. This means that wet deposition is gravitational, Brownian and/or turbulent coagulation with water droplets. Wet deposition involves two major processes: nucleation and within and below cloud scavenging, whereby the wet aerosol particles are collected by falling raindrops (Barrie \& Schemenauer, 1986). Wet deposition (via rain and other types of precipitation) is most efficient at removing soluble form of heavy metals from the air. A great percentage of metals fall through the rain at the place of their production (Nurnberg et al., 1984).

For example, dry deposition can remove gaseous mercury forms (particulate forms), while wet deposition is responsible for removing divalent mercury form (soluble form) (Nurnberg et al., 1984).

\subsection{Occult deposition}

Generally, this route is considered as one of the wet deposition processes. In occult deposition, wetted particles (fog and mist) are deposited by impaction or turbulent transfer (Barrie \& Schemenauer, 1986).

However, heavy metals are principally dispersed by atmospheric transportation (Dobrovolsky, 1980), but it is necessary to consider that most atmospherically dispersed heavy metals enter the soil surface and the aboveground plant tissues very rapidly. In the soil, they are sorbed by the absorption complex and redistributed through the soil profile. A proportion of heavy metals is taken up by plants and leached by surface and subterranean runoff. The need to control atmospheric contamination of soils by heavy metals and take preventive and remediation measures is dictated by the serious ecological consequences of this contamination, as observed in different regions of the world (Galiulin et al., 2002).

\section{Urgency of monitoring air contamination}

The degree and extent of environmental changes over the last decades has given a new urgency and relevance to the detection and understanding of environmental change, due to human activities, which have altered global biogeochemical cycling of heavy metals and other pollutants. Approximately 5 million chemicals are presently known and 80,000 in use; $500-1,000$ are added per year resulting in a progressive increase in the flux of bioavailable chemical forms to the atmosphere. Therefore air pollution has been one of the major threats to human health and the environment since the last century (Obbard et al., 2005; Batzias \& Siontorou, 2006; Dmuchowski \& Bytnerowicz, 2009).

\subsection{Approaches for monitoring air contamination}

There are two conceptual approaches for collecting samples relevant to air and atmospheric deposition related pollution studies. The first approach involves the direct collection of 
airborne particulate matter, precipitation and total deposit whereas the second approach uses air pollution biomonitors. The first approach is aimed at quantitative surveys at local, short-range, medium-range or global transport of pollutants, including health-related studies when collecting size fractionated airborne particulate matter. It requires continuous sampling on a long-term basis at a large number of sites, in order to ensure the temporal and spatial representativeness of measurements. The application of such direct measurements on a large scale is extremely costly and person-power intensive. Furthermore, it is not possible, due to logistic problems, to install instrumental equipment at all needed locations. Therefore, the second approach is considered as a non-expensive, yet reliable means of air quality status assessment in a country or a region. Certain types of biological organisms provide a measure of integrated exposure over a certain amount of time and enrich the substance to be determined so that the analytical accessibility is improved and the measurement uncertainty reduced. Sampling is relatively simple (even in remote areas and areas with difficult access) because of no expensive technical equipment is needed (Bagla et al., 2009). Furthermore, the sample treatment and analysis steps in the laboratory are facilitated (Wolterbeek, 2002) Also, this method avoids the need for deploying large numbers of precipitation collectors with an associated long-term program of routine sample collection and analysis (Harmens et al., 2008). Therefore, a much higher sampling density can be achieved than with conventional precipitation analysis and increases the possibility of monitoring many sites simultaneously (Wannaz et al., 2006). Also Bioindicators may be very useful due to their high sensitivity towards a broad spectrum of substances or because of their tolerance to high levels of a substance, accumulated in their tissues over an extended period of time or to integrate its influence in an area of known and relevant size (De Temmerman, 2004). Biomonitoring data are being compared with precipitation, particulate matter fractionation, and speciation data and also with medical statistics to evaluate the correlation between the amount of pollutants in the atmosphere and the human reaction to it (Szczepaniak \& Biziuk, 2003).

\subsection{Definition of biomonitoring and related terms}

The term bioindicator/biomonitor is used to refer to an organism, or a part of it, that depicts the occurrence of pollutants on the basis of specific symptoms, reactions, morphological changes or concentrations (Markert et al., 1997). There is considerable variation in the use of the terms bioindicator and biomonitor: A bioindicator is an organism (or part of an organism or a community of organisms) that contains information on the quality of the environment (or a part of the environment). A biomonitor, on the other hand, is an organism (or part of an organism or a community of organisms) that contains information on the quantitative aspects of the quality of the environment. The clear differentiation between bioindication and biomonitoring using the qualitative/quantitative approach makes it comparable to instrumental measuring systems (Markert, 2007). Therefore biomonitoring, in the general sense, may be defined as the use of organisms and biomaterials to obtain information on certain characteristics of the biosphere. With proper selection of organisms, the general advantage of the biomonitoring approach is related primarily to the permanent and common occurrence of the organism in the field, even in remote areas, the ease of sampling, and the absence of any necessary expensive technical equipment (Wolterbeek, 2002). 


\subsection{Classification of biomonitors}

Organisms can be classified according to the way in which the reaction is manifested: (1) reaction indicators, which have a sensitive reaction to air pollutants and which are used especially in studying the effects of pollutants on species composition, and on physiological and ecological functioning, and (2) accumulation indicators that readily accumulate a range of pollutants and are therefore used especially when monitoring the amount of pollutants and their distribution (Markert et al., 1997). Bioaccumulation monitoring methods can be divided into two groups: (Fig 2.)

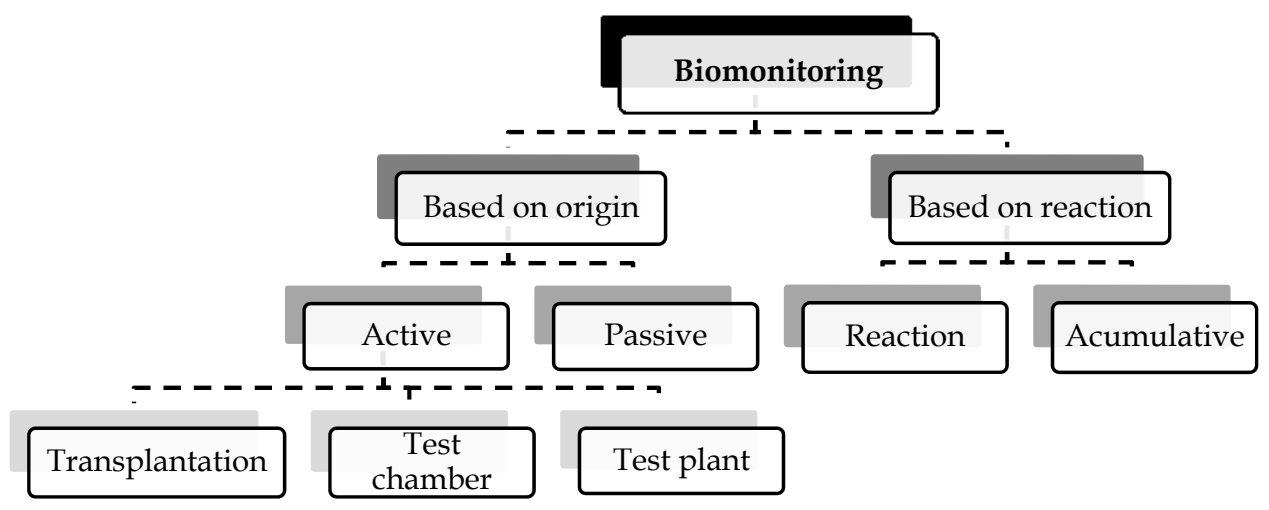

Fig. 2. General scheme of heavy metal biomonitoring using different materials and sampling techniques.

\subsubsection{Active biomonitoring}

Active biomonitoring includes the exposure of well-defined species under controlled conditions and can be divided into transplantation, test plant, and test chamber methods $\left(\mathrm{C}^{\vee}\right.$ eburnis \& Valiulis, 1999). In the transplantation procedure, suitable organisms (mainly mosses and lichens) are transplanted from unpolluted areas to the polluted site under consideration. The exposure time thus is well defined, but the change in uptake efficiency due to climatic change is usually applied to testing either synergistic or single species effects of pollutants on sensitive biomonitors. Transplant techniques appear to be useful, in particular at relatively high pollutant levels. One distinct advantage, compared to the use of indigenous species, is that of well-defined exposure time, but the reproducibility of this technique appears not to be very satisfactory for parameters such as air concentration and deposition rate ( $C^{\vee}$ eburnis and Valiulis, 1999).

\subsubsection{Passive biomonitoring}

Passive biomonitoring refers to the observation or chemical analysis of indigenous plants. In general, the passive biomonitoring method has one major disadvantage; all processes and all sources act at the same time and there is no possibility of separating them and looking for a particular one ( $\mathrm{C}^{\smile}$ eburnis and Valiulis, 1999). Natural variabilities in ambient macro and microclimate conditions, such as acidity, temperature, humidity, light, and altitude (Gerdol 
et al., 2002), or ambient elemental (nutritional) occurrences may cause the biomonitors to exhibit variable behavior. Part of this variance is local (Wolterbeek \& Verburg, 2002), but it may be clear that this variable behavior becomes a problem when it seriously affects the biomonitors in its accumulative exposure (Wolterbeek, 2002).

\subsection{Principles of bioaccumulation monitoring}

Biomonitoring is regarded as a means to assess trace element concentrations in aerosols and deposition. This implies that the monitor should concentrate the element of interest and quantitatively reflect its ambient conditions (Wolterbeek, 2002). In general, a good accumulation indicator of air pollutants should:

1. Accumulate pollutants from the air in the same way and to the same degree under different conditions (Wittig, 1993; Conti \& Cecchetti, 2001).

2. The pollutants should be easily measured and the measurements should provide information about the level of pollutant deposition.

3. It should also indicate the risk limits caused by increasing levels of pollutants.

4. The species of organism used should be common enough and be available for collection throughout the year in the same area.

5. Its use should be based on standard sampling and analysis methods.

6. In order to determine the state of the ecosystem in relation to the pollutant under study, the state of the ecosystem in the background area should also be known (Seaward 1995).

The background level is usually considered to be the "natural" level at which emissions have as small an effect as possible (Conti \& Cecchetti, 2001). The background level of different pollutants varies between plant species.

\subsection{Type of biomonitors}

As plants are immobile and more sensitive in terms of physiological reaction to the most prevalent air pollutants than humans and animals, they better reflect local conditions (Nali and Lorenzini 2007). For these reasons, plants are the most common used bioindicators in air quality biomonitoring studies (Balasooriya et al. 2009). Types of plant and their different parts have been applied in trace element air monitoring programs, such as lichens, mosses, ferns, grass, tree bark, tree rings, tree leaves and pine needles (Szczepaniak \& Biziuk, 2003; Morselli et al., 2004). For all biomonitors used, the mechanisms of trace element uptake and retention are still not sufficiently known. For grass, tree rings, and ferns, substantial element contributions from other sources than atmospheric, such as the soil or the tree bole, have to be taken into account (Szczepaniak \& Biziuk, 2003). Rossini Oliva and Mingorance (2006) reported that the accumulation pattern in the different parts of Pinus pinea L. and Nerium oleander L. was the following: wood < bark $\leq$ leaves, because of metals are taken up by wood stem from the soil and soil water, while the outer part (leaves and bark) intercept metals also by deposition from the atmosphere (Rossini Oliva \& Mingorance, 2006).

It is important to note that a unique species that can be a suitable bioindicator for biomonitoring of toxic metal pollution all over the world has not been found yet. But lower and higher plants use as suitable biomonitors world-wide. 
Plants accumulate metals due to many factors, such as element availability, the characteristics of the plants (such as species, age), state of health, and type of reproduction, temperature, available moisture, substratum characteristics, etc (Conti \& Cecchetti, 2001)

\subsubsection{Biomonitoring by lower plants}

Lower plants are resistant to many substances which are highly toxic for other plants species. They are able to survive in such diverse and often extreme environment; these sedentary organisms possess an equally diverse set of physiological adaptations (Cenci et al., 2003; Fernandez et al., 2006; Dragovič \& Mihailovič, 2009). Of all biological species used in biomonitoring, lichens and mosses have the most common occurrence. The morphology of lichens and mosses does not vary with seasons; thus accumulation can occur throughout the year. Lichens and mosses usually have considerable longevity, which led to their use as long-term integrators of atmospheric deposition (Szczepaniak \& Biziuk, 2003).

\subsubsection{Mosses as biomonitor}

Botanically, mosses are bryophytes ${ }^{1}$. About 15,000 species of mosses are known world-wide (Richardson, 1981), most of which are abundantly distributed amongst the different ecosystems, growing on a variety of substrates (Onianwa, 2000). Two Swedish scientists Åke Rühling and Germund Tyler (1960) have discovered that mosses are good bioindicator of heavy metal pollution in the atmosphere, after this successful discovery many European countries have used mosses in national and multinational surveys of atmospheric-metal deposition. Mosses are cryptogams that thrive in a humid climate. Ectohydric mosses have been used as biomonitors - in most cases terricolous bryophytes. They possess many properties that make them suitable for monitoring air pollutants (Onianwa, 2000). These species obtain nutrients from wet and dry deposition because of they do not have real roots so there is no uptake of mineral substrates from other sources than the atmosphere. Nutrient uptake from the atmosphere is promoted by their weakly developed cuticle (so metal ions easily penetrate the cell wall), large surface to weight ratio, and their habit of growing in groups. Other suitable properties include a slow growth rate, small size and easy to handle, undeveloped vascular bundles (so transport of minerals between segments is limited), minimal morphological changes during the mosses' lifetime, perenniality, wide distribution (even in industrial and urban areas), an ability to survive in highly polluted environment, ease of sampling and the possibility to determine concentrations in the annual growth segments (Poikolainen, 2004; Dragovič and Mihailovič, 2009).

Air pollutants are deposited on mosses in aqueous solution, in gaseous form or attached to particles. The accumulation of pollutants in mosses occurs through a number of different mechanisms:

- As layers of particles or entrapment on the surface of the cells.

- Incorporation into the outer walls of the cells through ion exchange processes

- Metabolically controlled passage into the cells (Poikolaonen, 2004).

The attachment of particles is affected e.g., by the size of the particles and the surface structure of the mosses.

${ }^{1}$ Contains Mosses and Liverworts 
Ion exchange is a fast physiological-chemical process that is affected e.g., by the number and type of free cation exchange sites, the age of the cells and their reaction to desiccation, growing conditions, temperature, precipitation $\mathrm{pH}$, composition of the pollutants and leaching (Brown \& Brûmelis 1996). In the ion exchange process, cations and anions become attached to functional organic groups in the cell walls among other things through chelation (Rao, 1984).

The cell wall has a high polyuronic acid content which makes moss a very good natural ion exchanger. The cell walls of bryophytes possess many negatively charged anionic sites to which cations are bound in exchangeable form. Studies of electron microscope have shown that the sorbed metal may be held either in the extracellular region outside of the cytoplasm, bound to the cell wall, and due to the highly reduced presence or absence of cuticle in the moss, ions have a direct access to the cell wall, mosses surfaces and rhizoids do not perform any active heavy metal ion discrimination (Shakya et al., 2008; Reimann et al., 2006; Onianwa, 2000).

Results of previous studies have shown that the degree of metal uptake efficiency retention proved to decrease in the order $\mathrm{Cu}>\mathrm{Pb}>\mathrm{Ni}>\mathrm{Co}>\mathrm{Cd}>\mathrm{Zn}$, Mn. Lead is very strongly fixed in the moss, and for this reason the correlation between concentration in moss and bulk deposition is particularly high (Szczepaniak \& Biziuk, 2003; Rosman, et al., 1998).

Mosses have been used for monitoring atmospheric heavy metal levels in various forms, these include indigenous naturally-occurring epiphytic forms, moss transplants, moss-bags, and Sphagnum mosses. The majority of investigations have utilised epiphytic mosses growing naturally at a given location. Such mosses may be found growing on rocks, tree barks, walls or forest floors, and may be of the acrocarpous or pleurocarpous types. Many species of mosses have been so used, but perhaps the most commonly reported in the literature are the species Hypnum cupressiforme, Hylocomium splendens, and Pleurozium schreberi, particularly in parts of Europe where they are largely abundant (Onianwa, 2000). The comparisons between indigenous and transplanted mosses are summarized in table 2.

Factors affecting on uptake efficiency by mosses

The chemical composition of deposition has a large effect on the accumulation of pollutants, because the uptake efficiency of mosses for individual elements varies considerably (Berg et al., 1995). A high proportion of the pollutant load accumulates in mosses through wet deposition. The amount, duration and intensity of precipitation affect accumulation and leaching (Berg et al. 1995). Ross (1990) and Berg et al (1995) found the best correlation between the concentrations in mosses and in wet deposition for elements such as $\mathrm{Pb}, \mathrm{Cd}, \mathrm{Co}$ and $\mathrm{Cu}$ that have high uptake efficiency from wet deposition. The contribution of dry deposition increases on moving from humid to arid climates (Couto et al., 2004). Uptake efficiency is also affected by competition for free cation exchange sites; for instance, the presence of sea salts and acidic deposition has been found to have an effect on the absorbtion of metals by mosses (Gjengedal \& Steinnes, 1990). The types of vegetation and soil dust have also been reported to cause regional differences in uptake efficiency (Szczepaniak \& Biziuk, 2003). Other factors affecting the concentrations include stand throughfall and leaching from vegetation layers located above the mosses (Steinnes, 1993), the nutrient status of the site (Pakarinen \& Rinne 1979; Økland et al., 1999) and snowmelt water (Ford et al. 1995). The altitude may also have an effect (Gerdol et al. 2002), due e.g., to changes in the amount of precipitation, dust or biomass production. The sampling and 
measuring methods employed can also have a considerable influence on the analytical results in biomonitoring studies (Steinnes et al. 1993; Wolterbeek \& Bode 1999).

\begin{tabular}{|c|c|}
\hline Indigenous & Transplants \\
\hline $\begin{array}{l}\text { Results of pollution patterns can be obtained } \\
\text { within a few days. }\end{array}$ & $\begin{array}{l}\text { A survey period of a year is required to allow } \\
\text { for effects of seasonal variation. }\end{array}$ \\
\hline $\begin{array}{l}\text { Results demonstrate pollution in previous } \\
\text { years. }\end{array}$ & $\begin{array}{l}\text { Results illustrate pollution only over the } \\
\text { sampling period. }\end{array}$ \\
\hline $\begin{array}{l}\text { Accumulation levels are usually above } \\
\text { detectable levels due to longer exposure time. }\end{array}$ & $\begin{array}{l}\text { Concentrations of accumulated levels may be } \\
\text { undetectable over shorter sampling period. }\end{array}$ \\
\hline $\begin{array}{l}\text { Minimal supervision and risk from } \\
\text { vandalism. }\end{array}$ & Potential risk from vandalism. \\
\hline $\begin{array}{l}\text { Costs acquired from transport to sites and } \\
\text { chemical analyses. }\end{array}$ & $\begin{array}{l}\text { Additional costs from materials, increased } \\
\text { transport and more sampler preparation. }\end{array}$ \\
\hline Potential shortage of indigenous samples. & $\begin{array}{l}\text { Density of sampling sites, samplers and their } \\
\text { position under the control of investigators. }\end{array}$ \\
\hline Pollution deposition rates difficult & $\begin{array}{l}\text { Deposition rates calculated from controlled } \\
\text { exposure time. }\end{array}$ \\
\hline $\begin{array}{l}\text { Metal concentrations reflect influences from } \\
\text { other factors such as age of plant, metal } \\
\text { content of substrate and local contamination. } \\
\text { Plants may be stressed or undergo } \\
\text { morphological/physiological changes, which } \\
\text { affect uptake, by long-term exposure to } \\
\text { certain pollutants. }\end{array}$ & $\begin{array}{l}\text { Pollutant concentrations in plants can be } \\
\text { more directly related to airborne pollution. }\end{array}$ \\
\hline
\end{tabular}

Table 2. Comparisons of indigenous samplers and transplants in heavy metal deposition monitoring (from Gailey and Lloyd, 1993).

It must be noted that the high concentrations of atmospheric pollutants such as sulphur dioxide and heavy metal particulates are harmful to the full development of mosses, and mosses do not thrive well around locations of such very high pollution levels (Onianwa, 2000).

\subsubsection{Lichens as biomonitor}

Lichens are the most studied biomonitors of air quality, since in 1866 a study was published on use of epiphytic lichens as bioindicators. They have been defined as "permanent control systems" for air pollution assessment (Conti \& Cecchetti, 2001). Because of their high sensitivity toward specific pollutants and ability to store contaminants in their biological tissues, lichens are defined as bioindicators and/or bioaccumulators, respectively. Lichen form conspicuous gray, green, orange, or red patches on trees or rockes (Blasco et al., 2008).

Lichens are perennial cryptogams. They live on different types of substrate, usually on dry or nutrient-poor sites in boreal and sub-arctic regions (Nash 1996). The lichen species best suited as biomonitors are foliose ${ }^{2}$ and fruticose ${ }^{3}$ epiphytic lichens. Lichens consist of a symbiotic association of two organisms: the fungal component is usually an Ascomycetes

2. Some lichens have the aspect of leaves

3. Some lichens adopt shrubby forms 
fungus (mycobiont), and the algal component (photobiont), a green alga (Chlorophyceae) and/or blue-green alga (Cyanobacteriae). The fungal component is responsible for taking up water and minerals, and the algal component, which grows amidst the fungal mycelia, for photosynthesis. Most lichen species obtain their nutrients from wet and dry deposition (Martin \& Coughtrey 1982; Garty 1993). The lichen surface, structure, and roughness facilitate the interception and retention particles (Szczepaniak \& Biziuk, 2003). They possess many of the same properties as mosses that make them suitable for monitoring purposes: the cuticle and vascular bundles are weakly developed, (means that the different pollutants are absorbed over the entire tallus surface of the organism), they do not have any real roots, they are slow-growing and long-lived, and they have an extremely broad distribution (Wolterbeek et al., 2003).

In general, three mechanisms have been reported with regard to the absorption of metals in lichens:

- Intercellular absorption through an exchange process

- Intercellular accumulation

- $\quad$ Entrapment of particles that contain metals (Szczepaniak \& Biziuk, 2003).

Lichens may be used as bioindicators and/or biomonitors in two different ways: (1) By mapping all species present in a specific area; entitled "mapping lichen diversity" that consists recording changes in arboreal species diversity in fixed plots over time, either through the use of grid or transects samples, using a standardized method develop by lichenologists and (2) Through the individual sampling of lichen species and measurement of the pollutants that accumulate in the thallus, or by transplanting lichens from an uncontaminated area to a contaminated one and then measuring the morphological changes in the lichen thallus and/or evaluating the physiological parameters and/or evaluating the bioaccumulation of the pollutants (Conti \& Cecchetti, 2001).

It was found that concentrations of $\mathrm{Pb}, \mathrm{Fe}, \mathrm{Cu}, \mathrm{Cr}$ and $\mathrm{Zn}$ in Hypogymnia physodes correlated strongly with annual average atmospheric deposition (Sloof, 1995).

In the context of pollution monitoring which uses naturally occurring lichens at monitoring sites as well as lichen transplants, changes in lichen morphology, cytology, metabolism and physiological processes, all provide environmental insight. Normal Hypogymnia physodes (L.) Nyl., for example, has a smooth, grey thallus with large lobes but when exposed to air pollution, the surface becomes cracked and the coloration brown or black (Richardson \& Nieboer, 1981)

\section{Factors affecting on uptake efficiency by lichen}

There are a considerable number of factors, associated with the site where lichens are growing, which may change the concentrations of pollutants in lichens (Brown, 1991; Garty, 2000). These factors are, in most cases, the same as those affecting mosses including quality of the deposition (form of occurrence, composition, $\mathrm{pH}$ ), climate (composition of precipitation, temperature, wind, drought, length of the growing period) and local environmental factors (vegetation, quality of the substrate, stand throughfall and stemflow, dust derived from soil, altitude of area). On the other hand, throughfall and stemflow, which vary according to the type of canopy cover, have a greater effect on epiphytic lichens than on terricolous mosses (Poikolainen, 2004; Rasmussen, 1978). 
Most species are especially sensitive to $\mathrm{SO}_{2}$, nitrogen and fluoride compounds and to ozone. These compounds affect the condition of lichens and thus reduce the capacity of lichens to accumulate and absorb elements from the atmosphere (Poikolainen, 2004).

Air pollutants have a different effect on the fungal and on the algal partner. The algal partner has been reported to react more sensitively e.g., to acidic deposition and heavy metals, and to show varying accumulation of metals depending on the acidity of precipitation. Sporadic desiccation of lichens may also have an effect on the accumulation and absorption of elements (Poikolainen, 2004). After a dry period, rainfall may result in appreciable washing off particles and the exchange of cations bound on negatively charged exchange sites on the cell walls and plasma membranes of the cells (Bargagli, 1998).

Results of different studies about heavy metal concentrations in various lichen species are summarized in table 3 . There are clear differences in the accumulation of elements between different lichen species (even in the same studies) as a result of morphological and physiological differences.

\begin{tabular}{|c|c|c|c|c|c|c|c|c|}
\hline & $\begin{array}{l}\text { Lichens } \\
\text { (Bowen, } \\
1979)\end{array}$ & $\begin{array}{l}\text { Pseudevernia } \\
\text { furfuracea } \\
\text { (Adamo, } \\
\text { 2003) }\end{array}$ & $\begin{array}{c}\text { Foliose (e.g. } \\
\text { Parmelia, } \\
\text { Hypogymnia) } \\
\text { (Adamo, 2003) }\end{array}$ & $\begin{array}{l}\text { Evernia } \\
\text { prunastri } \\
\text { (Conti, } \\
2004)\end{array}$ & $\begin{array}{c}\text { Dirinaria } \\
\text { picta } \\
\text { (NG et al., } \\
\text { 2006) }\end{array}$ & $\begin{array}{c}\text { C.rangiformis } \\
\text { (Cayir et al., } \\
\text { 2007) }\end{array}$ & $\begin{array}{c}\text { Pyxine } \\
\text { cocoes } \\
\text { (Rajesh et } \\
\text { al., 2011) }\end{array}$ & $\begin{array}{c}\text { Phaeophyscia } \\
\text { hispidula } \\
\text { (Rajesh et } \\
\text { al., 2011) }\end{array}$ \\
\hline$\overline{C d}$ & - & 0.46 & $(<0.1-0.3)$ & $\begin{array}{c}(0.05-0.09) \\
\end{array}$ & $(0.14-0.28)$ & $\overline{(0.14-0.69)}$ & $(0.9-6.3)$ & $(0.8-6.8)$ \\
\hline $\mathrm{Cr}$ & (0.6-7.3) & 2.23 & $(1-4)$ & (1.04-2.81) & - & $(2.24-13.0)$ & $(0.8-26.2)$ & $(3.4-35.2)$ \\
\hline $\mathrm{Cu}$ & $(9-24)$ & 5.42 & $(4-10)$ & (1.94-4.45) & (11.75-45.13) & (1.06-5.29) & - & - \\
\hline $\mathbf{P b}$ & (1-78) & 23 & $(1-8)$ & (1.05-3.62) & $(2.83-16.59)$ & $(1.35-33.8)$ & $(0.1-13.3)$ & $(4.4-11.7)$ \\
\hline Zn & $(20-60)$ & 99 & $(20-90)$ & (20.3-53.2) & $(44.17-83.15)$ & (9.15-47.6) & (57.3-194.4) & $(103.1-214.6)$ \\
\hline
\end{tabular}

Table 3. Heavy metal concentrations in lichen species from different studies $(\mathrm{mg} / \mathrm{kg})$, (ranges in brackets).

\subsubsection{Moss to lichens comparison}

As above mentioned mosses and lichens do not have root systems like higher plants therefore their contaminant content depend on surface absorption. These organisms have been shown to concentrate particulates and dissolve chemical species from dry and wet deposition. Differences in substrata result in differences in lichen metal content. For mosses, relatively high contribution of crustal elements such as $\mathrm{Al}, \mathrm{Sc}$, $\mathrm{La}$ and lanthanides is observed. The increase in cation exchange capacity from moss apex to base is apart of its natural balance of elements, which in turn is affected by the proximity of the soil.

Lichen identification and collecting turns out to be very complicated, whereas for mosses it is much easier. The annual growth increment is easier to distinguish for mosses than for lichens; therefore they are considered superior to lichens, if any time resolution in the measurement is required. Older parts of lichens carry fruiting bodies rich in metals. Mosses build carpets during a period of 3-5 years, and their metal content is generally considered to reflect the atmospheric deposition during that period (Szczepaniak \& Biziuk, 2003). Loppi and Bonini showed that lichens and mosses can be used indifferently as accumulators of As, Cd, Cu, Mo, and $S$. Differences in concentrations between lichens and mosses were statistically significant $(\mathrm{P}<0.05)$ for $\mathrm{Al}, \mathrm{B}, \mathrm{Fe}, \mathrm{Hg}, \mathrm{Pb}, \mathrm{Sb}$ and $\mathrm{Zn}$, with mosses retaining higher values than lichens except for $\mathrm{Hg}$ and $\mathrm{Zn}$. The elements found in higher concentrations in mosses were associated with particulate matter (Szczepaniak \& Biziuk, 2003). Bargagli et al. found higher 
concentrations of lithophile elements $(\mathrm{Al}, \mathrm{Cr}, \mathrm{Fe}, \mathrm{Mn}, \mathrm{Ni}$, and $\mathrm{Ti}$ ) in moss and atmophile elements ( $\mathrm{Hg}, \mathrm{Cd}, \mathrm{Pb}, \mathrm{Cu}, \mathrm{V}$, and $\mathrm{Zn}$ ) in lichen (Bargagli et al., 2002). According to studies of Kansanen and Venetvaara (1991) mosses and lichens as the most effective indicators for low and moderate level of metal deposition in polluted areas.

\subsubsection{Biomonitoring by higher plants}

However mosses and lichens most frequently used for monitoring metal pollution, but these lower plants are characterized by irregular and patchy distribution and their sampling should be done by specialists who can differentiate between similar-looking species. These limitations become more pronounced in industrial and densely populated areas, where sever anthropogenic pressure may cause scarcity or even lack of indicator species at some sampling points. For instance lichens are characterized by slow regeneration and relatively weak tolerance to the complex influence of mycophytotoxic pollutants, Therefore intensive sampling may lead to their reduced availability and even disappearance (Berlizov et al., 2007).

The use of higher plants, especially different parts of trees (leaves and barks), for air monitoring purposes is becoming more and more widespread. The main advantages are greater availability of the biological material, simplicity of species identification, sampling and treatment, harmless sampling and ubiquity of some genera, which makes it possible to cover large areas. Higher plants also exhibit greater tolerance to environmental changes which is especially important for monitoring areas with elevated anthropogenic influence (Berlizov et al., 2007), therefore higher plants have appeal as indicators in air pollution monitoring in highly polluted areas where lichens and mosses are often absent.

Higher plants not only intercept pollutants from atmospheric deposition but also accumulate aerial metals from the soil. Aerial heavy metal depositions are taken up from the soil by plants via their root system and translocated them to other parts of the plant (Mulgrew \& Williams, 2000). An otherwise in the industrial and urban areas, higher plants can give better quantifications for pollutant concentrations and atmospheric deposition than non-biological samples (Markert, 1993).

Some plant species are sensitive to single pollutants or to mixtures of pollutants. Those species or cultivars are likely to be used in order to monitor the effects of air pollutants as bioindicator plants (DeTemmerman et al., 2005).

In general, it can be assumed two separated groups of higher plants for biomonitoring purposes including herbs/grasses and trees/shrubs on both groups, aboveground plant tissues (leaf and bark) contribute in airborne heavy metal accumulation.

\subsubsection{Herbs and grasses as biomonitor}

Kovács (1992a) recommended the use of ruderal plants as bioaccumulative indicators due to their ability to accumulate metals in high quantities without visible injury (Kovács, 1992a).

Some plant species may be more efficient in retaining atmospheric metal particles than others. A measure of this efficiency can be resolved by calculating air accumulation factors (AAF) according to the following equation:

$$
\operatorname{AAF}\left(\mathrm{m}^{3} \cdot \mathrm{g}^{-1}\right)=\text { PAc }\left(\mathrm{mg} \cdot \mathrm{g}^{-1} \text { dry weight }\right) / \mathrm{CA}\left(\mathrm{mg} \cdot \mathrm{m}^{-3}\right)
$$


PAc $=$ atmospheric contribution of the metal in plants and CA $=$ concentration of the metal in the atmosphere (Mulgrew \& Williams, 2000).

\subsubsection{Trees and shrubs as biomonitor}

Both coniferous and deciduous trees can be used in the detection of aerial heavy metal pollution, but Coniferous trees indicate pollution over a longer time period such as, Pinus eldarica, Cupressus arizonica (Ataabadi et al., 2010a), Pinus brutia (Baslar et al., 2009), Cupressus semervirens (El-Hasan et al., 2002). Broad-leaved tree species regarded as sensitive to metal contamination include Betula pendula, Fraxinus excelsior, Sorbus aucuparia, Tilia cordata and Malus domestica (Mulgrew \& Williams, 2000). Numerous bioaccumulative indicators exist; some tree examples include Ailanthus glandulosa, Celtis occidentalis, Salix alba, Tilia tomentosa, Sambucus nigra, Quercus robur, Fagus silvatica (Mulgrew \& Williams, 2000) and Elaeagnus angustifolia (Akosy and Sahin, 1999). Also results of studies indicate that Robinia pseudoacacia (black locust tree) is appropriate species because of this tree is genetically homogeneous, easily identifiable and ubiquitously distributed (Kovács, 1992b).

However, there are limited studies about biomonitoring by shrub species, but it could numbered some shrub species such as Nerium oleander (Ataabadi et al., 2010a; Rossini Oliva \& Mingorance, 2006), Lantana Camara (Fernandez Espinoza \& Rossini Oliva, 2005) Ligustrum vulgare, Photinia serrulata, Berberis vulgaris and Thuja orientalis (Ataabadi et al., 2010a,b; Ataabadi et al., 2011).

For comparative studies, it is important that sampling is undertaken at the same time of the year to reduce variability. Chemical composition of foliage varies with season and rainfall (Taylor et al., 1990). For most deciduous species, suitable time is period of year when metal content in leaves will be highest. For instance standard sampling of heavy metal accumulation in Populus nigra in central Europe is carried out in August.

Metal content will vary depending on which part of the plant is sampled. The extent of accumulation in different plant parts will vary with species and the nature of the element.

It should be noted that using transplantation exercises are not common for higher plants (Mulgrew \& Williams, 2000).

\subsection{Plant leaves as biomonitor}

Leaves of higher plants have been used for heavy metals biomonitoring since 1950s (AlShayeb eta 1., 1995). The use of leaves as bioindicators of environmental pollution has been studied, more and more, to assess their suitability, to assess effect of a specific pollution source, to differentiate between background (unpolluted) and polluted sites and to monitor or assess the level of pollution in an area (Turan et al., 2011).

Rossini Oliva \& Mingorance (2006) and Ataabadi et al (2010a), reported that pine needles can be considered suitable biomonitor for atmospheric heavy metal contamination (e.g. $\mathrm{Fe}, \mathrm{Al}, \mathrm{Pb}$ ).

Factors that affect efficiency of heavy metal accumulation on leaf surface

Particle (containing heavy metals) deposition on leaf surfaces may be affected by two different factors including plant-dependent factors such as morphological and structural properties of leaves contain orientation and size (Mulgrew \& Williams, 2000) of leaves, 
cuticle thickness, cork existence, roughness, existence of surface waxy layer, specific leaf area (SLA), stomatal density (SD) and stomatal pore surface (SPS) (Ataabadi et al., 2011; Rossini Oliva \& Mingorance, 2006; Balasooriya et al. 2008) and plant-free factors such as particle size and wind velocity (Mulgrew \& Williams, 2000). Also the accumulation of heavy metals by higher plants depends on the binding and solubility of particles deposited on leaf surfaces (Mankovska et al., 2004).

The deposited particles may be washed by rain into the soil, resuspended or retained on plant foliage. The degree of retention is influenced by weather conditions, nature of pollutant, plant surface characteristics and particle size (Harrison and Chirgawi, 1989).

Leaves of evergreen species are considered to be better traps because of higher accumulation on a longer period of time (Turan et al., 2011).

\subsection{Plant bark as biomonitor}

The physiological function of bark is to protect the tree from mechanical injury, damaging agents and excessive evaporation. Bark quality varies considerably in different tree species and at different stages in the lifetime of a tree species. The outer bark of trees consists of the inner layer (phloem), the cork-forming layer (phellogen), and the outer layer (rhytidom or phellem) composed of dead cork cells (Prance et al., 1993). This dead cork layer has usually been employed in biomonitor studies. The chemical composition of the bark is specific to each tree species. For instance, the $\mathrm{pH}$, electrical conductivity and ash content of the bark of coniferous trees are usually lower than those of broad-leaved species (Barkman, 1958). When bark is exposed to air pollutants either directly from the atmosphere or from the rainwater running down the stem, the chemical composition of the surface layers of the bark changes, such changes can be utilised in investigating the extent of the area subjected to air pollutants. In this respect tree bark is a good bioindicator because it remains in place for an extended period of time, it is easily accessible and sampling does not damage the tree (Berlizov eta al., 2007). Retention of suspended particles is promoted by a moist, porous, rough, or electrically charged surface, making bark a highly effective collector (Panichev et al., 2004). Therefore bark has been widely employed as a passive monitor for airborne metal contaminations. The accumulation of atmospheric pollutants in bark is purely a physiological-chemical process. The pollutants either accumulate passively on the bark surface or become absorbed through ion exchange processes in the outer parts of the dead cork layer (Poikolainen, 2004). Although a number of air pollution biomonitoring studies have been performed using bark of different tree species include oak, elm, willow, poplar, pine, olive, cedar, eucalyptus etc. (Berlizov et al., 2007).

Metal accumulation in bark and plant foliage in urban and industrial areas can be considerable, with the greatest amount of the heavy metal burden located in the bark (Ce^burnis \& Steinnes, 2000; Watmough \& Hutchinson, 2003).

Factors that affect efficiency of heavy metal accumulation on bark surface

Factors, in addition to atmospheric pollutants, that affect the chemical composition of tree bark are mainly the same as those for mosses and lichen, although the chemical reactions that occur in bark are somewhat different because bark is a non-living plant material. The concentrations in bark are mainly affected by bark quality, stand throughfall and stem flow. The concentrations are highest in the surface layers of the outer bark, and decrease rapidly on moving towards the inner layers. Many different factors have an effect on the collecting 
of heavy metals in bark surface, such as heavy metal quantities in air, physiological and chemical properties of the bark, through fall, soil factors, contamination of other plants, climate factors, etc. A coarse and rough surface more readily accumulates atmospheric pollutants than a smooth surface (Poikolainen, 2004), As Barnes et al., (1976) showed that rough barks accumulate metals more than smooth barks. Other factors include the bark texture and thickness (Poikolainen, 2004), the presence of epiphytic organisms, the time of exposure to the atmosphere and the depth of sampling (Bellis et al., 2001). Also bark acidity has an effect on the concentrations of some heavy metals. For instance, Bates and Brown (1981) found a clear negative correlation between bark $\mathrm{pH}$ and the Fe concentration in a study on the occurrence of epiphytic lichens on oak and ash. They concluded that this is due to the increased mobility of Fe with decreasing bark $\mathrm{pH}$. There is no significant migration of elements from the bark surface through the cork tissue into the underlying wood, or vice versa. The migration of heavy metals from the soil via the roots into the bark as it is being formed is also usually insignificant. On the other hand, heavy metals and other compounds may be carried by the wind from the soil to the bark surface (Poikolainen, 2004).

The study carried out by Szopa et al (1973) on lead concentrations along highways in the US indicated that the lead concentration in bark reacts rapidly to marked changes in lead concentrations in the atmosphere (Poikolainen, 2004).

\subsection{Analytical method}

Finally, the choice of analytical method for heavy metal detection in all plant materials depends on the purpose of the respective survey. Some analytical methods are nondestructive (e.g. Neutron Activation Analysis: N.A.A.) and are useful for repetitive surveys such as baseline studies. Samples can also be archived and used at a later date for additional analysis. Destructive techniques include atomic absorption spectrometry (AAS) and inductively coupled plasma (ICP) analysis (Mulgrew \& Williams, 2000).

On consideration of the methods available for moss monitoring in Norway, Steinnes et al. (1993) concluded that ICP-ES works well for $\mathrm{Fe}, \mathrm{Zn}, \mathrm{Pb}$ and $\mathrm{Cu}$, to a lesser extent for $\mathrm{V}$ and $\mathrm{Ni}$ and but is not satisfactory for $\mathrm{Cr}, \mathrm{Cd}$ and As. ICP-MS analysis proves a good method for all of the above except $\mathrm{As}$ and $\mathrm{Cd}$ where less satisfactory results were observed (Steinnes, 1993).

\subsection{Some atmospheric heavy metal contamination indices}

Several integrated environmental indices reflecting the quality of environment and life have begun to appear in recent years. On the other hand, quantitative information can be obtained by calculating different indices to estimate air quality (Calvelo \& Liberatore, 2004).

\subsubsection{Index of Atmospheric Purity (IAP)}

DeSloover(1964) and DeSloover and LeBlanc (1968) suggested the IAP method for mapping air pollution on the basis of epiphytic lichen and bryophyte sensitivity for mapping aerial pollution (Moore, 1974). This method is based on the fact that the epiphytic lichen and mosses diversity is impaired by air pollution and environmental stress. Therefore the frequency of occurrence of species on a defined portion of a tree trunk is used as a parameter to estimate the degree of environmental stress. This index gives an evaluation of 
the level of atmospheric pollution, which is based on the number, frequency, and tolerance of the epiphytic species present in an area.

$$
\operatorname{IAP}=\sum_{\mathrm{i}=1}^{\mathrm{n}}\left(\mathrm{Q}_{\mathrm{i}} \times \mathrm{f}_{\mathrm{i}}\right)
$$

$\mathrm{n}$, the number of epiphytic species per site; $\mathrm{Q}_{\mathrm{i}}$, the resistance factor or ecological index of each species, thus representing the sensibility of a species against pollutants; $f_{i}$, the frequency or coverage score of each species per site (Max. 10; $1 \leq \mathrm{f} \leq 10$ ). The IAP-index was calculated separately for each sampling site (Blasco et al., 2008; Zechmeister \& Hohenwallner, 2006).

The frequency method makes it possible to predict pollution levels with a certainty of over 97\% (Conti \& Cecchetti, 2001). After calculation of IAP, pollution intensity will be determined by IAP classification is shown in Table 4 .

\begin{tabular}{lll}
\hline Level A & $0 \leq$ IAP $\leq 12.5$ & Very high level of pollution \\
Level B & $12.5 \leq$ IAP $\leq 25$ & High level of pollution \\
Level C & $25 \leq$ IAP $\leq 37.5$ & Moderate level of pollution \\
Level D & $37.5 \leq$ IAP $\leq 50$ & Low level of pollution \\
Level E & IAP $>50$ & Very low level of pollution \\
\hline
\end{tabular}

Table 4. Quality levels of index of atmospheric purity (IAP) (from Szczepaniak \& Biziuk, 2003).

Quality levels may somewhat differ in various studies. As Dymytrova (2009) studied a total of 1730 trees and 272 sampling plots in different parts of Kyiv (Ukraine) including industrial areas, residential areas, roads and inner parks and investigated epiphytic bryophytes and lichens on isolated trees. Results showed the highest and lowest epiphytic richness in the inner parks and industrial area respectively. Consequently based on IAP, four zones with different air pollution were distinguished: highly polluted (0-8.5), moderately polluted (8.620.2), slightly polluted (20.3-31.9) and unpolluted (32-88.8). In these studies, heavy metal concentrations in epiphytic vegetation and quality levels of IAP are correlated.

\subsubsection{Enrichment factor}

One approach used to characterize airborne particulate matter in terms of chemical composition is to calculate so called 'enrichment factors' (EF), relating the concentration of an anthropogenic 'pollutant' element $(\mathrm{X})$, such as $\mathrm{Pb}$, to that of a crustal element (typically $\mathrm{Al}, \mathrm{Ti}, \mathrm{Sc}$ or $\mathrm{Fe}$ ) in air, normalized to the ratio of these elements in the average continental crust:

$$
\mathrm{EF}=\left(\mathrm{X}_{\text {air }} / \mathrm{Al}_{\text {air }}\right) /\left(\mathrm{X}_{\text {crust }} / \mathrm{Al}_{\text {crust }}\right)
$$

Enrichment factors close to unity thus indicate that windblown dusts are the dominant airborne source, whilst values in excess of unity indicate that analyte concentrations have been elevated as a result of anthropogenic inputs. The calculation assumes that the anthropogenic contribution of the normalizing element (i.e. Al) is insignificant (Zoller et al., 1974; Puxbaum, 1991).

Pacheco et al. (2002) evaluated olive-tree bark for the biological monitoring of airborne trace elements and found significant enrichment of $\mathrm{Cu}$ in olive bark relative to Parmelia spp. lichen was reported (Pacheo et al., 2002). 


\section{Conclusion}

Application of lower and higher plants as biomonitors seams to be a good way to monitor airborne heavy metal contamination, but the choice of proper phytomonitor for environmental studies depends on many factors such as availability of the biological material, contamination extent, study scale and etc. However lichen and moss due to have superior ability to accumulate elements and indicate them without interference with soil are reported the best bioindicators for the atmospheric heavy metal contamination, but in the urban and industrial areas, using aboveground parts of indigenous higher plants is recommended. Simplicity of species identification, sampling and treatment and ubiquity of some genera makes it possible to cover large areas. For the comprehensive conclusion, both of lower and higher plants should be studied simultaneously in the specific area and manifested with respect to their limitations and advantages.

\section{Acknowledgment}

The authors would like to thank Dr. Ahmad Ali Foroughi, the chancellor of Islamic Azad University Khorasganan branch (Isfahan) and Research Center of this University.

\section{References}

Adamo, P.; Giordano, S. Vingiani, S. Cobianchi, R.C. \& Violante, P. (2003). Trace Element Accumulation by Moss and Lichen Exposed in Bags in the City of Naples (Italy). Environmental Pollution, Vol.122, No.1, (2003), pp. 91-103, ISSN 0269-7491

Adriano, D. C. (1986). Trace Elements in the Terrestrial Environment. Springer, New York.

Akosy, A. (2008). Chicory (Cichorium intybus L.): A Possible Biomonitor of Metal Pollution. Pakistan Journal of Botany, Vol.40, No. 2, (1986), pp. 791-797, ISSN 0556-3321

Akosy, A.; \& Sahin, U. (1999). Elaeagnus angustifolia L. as a Biomonitor of Heavy Metal Pollution. Turkish Journal of Botany, Vol.23, No.2, (1999), pp. 83-87, ISSN 1300-008X

Al-Shayeb, S.M.; Al-Rajhi, M. A. \& Seaward, M.R.D. (1995).The Date Palm (Phoenix dactylifera L.) as a Biomonitor of Lead and Other Elements in Arid Environments. Science of the Total Environment, Vol.168, No.1, (1995), pp. 1-10, ISSN 0048-9697

Ataabadi, M.; Hoodaji, M. \& Najafi, P. (2010a). Heavy Metal Biomonitoring by Plants Grown in an Industrial Area of Isfahan Mobarakeh Steel Company. Journal of Environmental Studies, Vol.35, No. 53, (2010), pp. 83-92, ISSN 1025-8620

Ataabadi, M.; Hoodaji, M. \& Najafi, P. (2010b). Evaluation of Airborne Heavy Metal Contamination by Plants Growing Under Industrial Emission. Environmental engineering and Management Journal, Vol.9, No. 7, (2010), pp. 903-908, ISSN 1582-9596

Ataabadi, M.; Hoodaji, M. \& Najafi, P. (2011). Biomonitoring of Some Heavy Metal Contaminations from a Steel Plant by Above Ground Plants Tissue. African Journal of Biotechnology, Vol.10, No.20, (2011), pp. 4127-4132, ISSN 1684-5315

Avino, P.; Capannesi, G. \& Rosada, A. (2008). Heavy Metal Determination in Atmospheric Particulate Matter by Instrumental Neutron Activation Analysis. Microchemical Journal, Vol.88, No.2, (2008), pp.97-106, ISSN 0026-265X

Bajpai, R.; Mishra, G.K. Mohabe, S. Upreti, D.K. \& Nayaka, S. (2011). Determination of Atmospheric Heavy Metals Using Two Lichen Species in Katni and Rewa cities, India. Journal of Environmental Biology, Vol.32, No.2, (2011), pp. 195-199, ISSN 02548704 
Balasooriya, B.L.W.K.; Samson, R. Mbikwa, F. \& Vitharana, U.W.A. (2009). Biomonitoring of Urban Habitat Quality by Anatomical and Chemical Leaf Characteristics. Environmental and Experimental Botany, Vol.65, No. 2-3, (2009), pp. 386-394, ISSN 0098-8472

Bargagli, R. (1998). Trace elements in terrestrial plants: An Ecophysiological Approach to Biomonitoring and Biorecovery, Springer, ISBN 3540645519, Berlin, New York

Bargagli, R.; Monaci, F. Borghini, F. Bravi, F. \& Agnorelli, C. (2002). Mosses and Lichens as Biomonitors of Trace Metals. A Comparison Study on Hypnum cupressiforme and Parmelia caperata in a Former Mining District in Italy. Environmental Pollution, Vol.116, No.2, (2002), pp. 279-287, ISSN 0269-7491

Barnes, D.; Hammadah, M.A. \& Ottaway, J.M. (1976).The Lead, Copper, and Zinc Contents of Tree Rings and Barks, a Measurement of Local Pollution. Science of the Total Environment, Vol.5, No.1, (1976), pp. 63- 77, ISSN 0048-9697

Barrie, L.A. \& Schemenauer, R.S. (1986). Pollutant Wet Deposition Mechanisms in Precipitation and Fog Water. Water, Air, \& Soil pollution, Vol.30, No. 1-2, (1986), pp. 91-104, ISSN 0049-6979

Baslar, S.; Dogan, Y. Durkan, N \& Bag, H. (2009). Biomonitoring of Zinc and Manganese in Bark of Turkish Red Pine of Western Anatolia. Journal of Environmental Biology, Vol.30, No. 5, (2009), pp. 831-834, ISSN 0254-8704

Bates, J.W. \& Brown, D.H. (1981). Epiphyte Differentiation Between Quercus petraea and Fraxinus excelsior Trees in a Maritime Area of South West England. Vegetatio, Vol.48, No.1, (1981), pp. 61-70, ISSN 00423106

Batzias, F. A. \& Siontorou, Ch. G. (2006). A knowledge - based Approach to Environmental Biomonitoring. Environmental Monitoring and Assessment, Vol.123, No.1-3, (2006), pp. 167-197, ISSN 0167-6369

Beijer, K.; \& Jernelöv, A. (1986). Sources, Transport and Transformation of Metals in the Environment, In: Handbook on the Toxicology of Metals, L. Frindberg, G.F. Nordberg, V.B. Vouk, (Eds.), 68-74, Elsevier Scientific Publication, ISBN 0444904131, Amsterdam

Bellis, D.; Cox, A.J. Staton, I. McLeod, C.W. \& Satake, K. (2001). Mapping Airborne Lead Contamination Near a Metals Smelter in Derbyshire, U.K.: Spatial Variation of $\mathrm{Pb}$ Concentration and 'Enrichment Factor' for Tree Bark. Journal of Environmental Monitoring, Vol.3, No.5, (2001), pp. 512-514, ISSN 1464-0325

Berg, T.; Røyset, O. \& Steinnes, E. (1995). Moss (Hylocomium splendens) Used as Biomonitor of Atmospheric Trace Element Deposition: Estimation of Uptake Efficiences. Atmospheric Environment, Vol.29, No.3, (1995), pp. 353-360, ISSN 1352-2310

Berlizov, A.N.; Blum, O.B. Filby, R.H. Malyuk, I.A. \& Tryshyn, V.V. (2007). Testing Applicability of Black Poplar (Populus nigra L.) Bark to Heavy Metal Air Pollution Monitoring in Urban and Industrial Regions. Science of the Total Environment,Vol. 372, No.2-3, (2007), pp. 693-706, ISSN 0048-9697

Blasco, M.; Domeno, C. \& Nerin, C. (2008). Lichens Biomonitoring as Feasible Methodology to Assess Air Pollution in Natural Ecosystems: Combined study of quantitative PAHs Analyses and Lichen Biodiversity in the Pyrenees Mountains. Analytical and Bioanalytical Chemistry, Vol.391, No.3, (2008), pp. 759-771, ISSN 1618-2642

Bowen, H.J.M. (1979). Environmental Chemistry of the Elements, Academic Press, ISBN 0121204502, New York 
Brown, D.H. \& Brûmelis, G. (1996). A Biomonitoring Method Using the Cellular Distribution of Metals in Moss. Science of the Total Environment, Vol.187, No.2, (1996) pp. 153-161, ISSN 0048-9697

Brown, D.H. (1991). Lichen Mineral Studies - Currently Clarified or Confused. Symbiosis, Vol.11, No.2-3, (1991), pp. 207-223, ISSN 0334-5114

C`eburnis, D. \& Valiulis, D. (1999). Investigation of Absolute Metal Uptake Efficiency from Precipitation in Moss. Science of the Total Environment, Vol.226, No.2-3, (1999), pp. 247-253, ISSN 0048-9697

Calvelo, S. \& Liberatore, S. (2004). Applicability of In Situ or Transplanted Lichens for Assessment of Atmospheric Pollution in Patagonia, Argentina. Journal of Atmospheric Chemistry, Vol.49, No.1-3, (2004), pp. 199-210, ISSN 0167-7764

Cayir, A.; Coskun, M. \& Coskun, M. (2007). Determination of Atmospheric Heavy Metal Pollution in Canakkale and Balikesir Provinces Using Lichen (Cladonia rangiformis) as a Bioindicator. Bulletin of Environmental Contamination and Toxicology, Vol.79, No.4, (2007), pp. 367-370, ISSN 0007-4861

Ce^burnis, D. \& Steinnes, E. (2000). Conifer Needles as Biomonitors of Atmospheric Heavy Metal Deposition: Comparison with Mosses and Precipitation, Role of the Canopy. Atmospheric Environment, Vol.34, No.25, (2000), pp. 4265- 4271, ISSN 1352-2310

Cenci, R.M.; Sena, F. Bergonzoni, M. Simonazzi, N. Meglioli, E. Canovi, L. Locoro, G. \& Trincherini, P. (2003). Use of Mosses and Soils for the Monitoring of Trace Elements in Three Landfills, Used as Urban Waste Disposal Sites, Proceedings of Sardinia 2003 9th International Waste Management and Landfill Symposium, Italy, October 6-10,2003

Conti, M.E. \& Cecchetti, G. (2001). Biological Monitoring: Lichens as Bioindicators of Air Pollution Assessment--a Review. Environmental Pollution, Vol.114, No.3, (2001), pp. 471-492, ISSN 0269-7491

Conti, M.E.; Tudino, M. Stripeikis, J. Cecchetti, G. (2004). Heavy Metal Accumulation in the Lichen Evernia prunastri Transplanted at Urban, Rural and Industrial Sites in Central Italy. Journal of Atmospheric Chemistry, Vol.49, No.1-3, (2004), pp. 83-94, ISSN 0167-7764

Couto, J.A.; Fernández, J.A. Aboal, J.R. \& Carballeira, A. (2004) Active Biomonitoring of Element Uptake with Terrestrial Mosses: a Comparison of Bulk and Dry Deposition. Science of the Total Environment, Vol.324, No.1-3, (2004), pp. 211-222, ISSN 0048-9697

De Temmerman, L.; Bell, J.N.B. Garrec, J.P. Klumpp, A. Krause, G.H.M. \& Tonneijck, A.E.G. (2004). Biomonitoring of Air Pollution with Plants Considerations for the Future, In: Urban Air Pollution, Bioindication and Environmental Awareness, A. Klumpp, W. Ansel, G. Klumpp, (Eds.), 337-373, Cuvillier Verlag, ISBN 3865370780, Go“ttingen

De Temmerman, L.; Nigel, J. Bell, B. Garrec, J.P. Klumpp, A. Krause, G. H. M. \& Tonneijck, A. E. G. (2005). Biomonitoring of Air Pollutants with Plants, In: International society of environmental Botanists, Vol.11, No.2, Available form:

http://isebindia.com/05_08/05-04-1.html

Dmuchowski, W. \& Bytnerowicz, A. (2009). Long-term (1992-2004) Record of Lead, Cadmium, and Zinc Air Contamination in Warsaw, Poland: Determination by Chemical Analysis of Moss Bags and Leaves of Crimean linden. Environmental pollution, Vol.157, No.12, (2009), pp. 3413-3421, ISSN 0269-7491 
Dobrovolsky, V.V. (1980). Heavy Metals: Environmental Contamination and Global Geochemistry, In: Heavy Metals in the Environment, V.V. Dobrovolsky, (Ed.), 3-12, Moscow State University Publishing House, Moscow

Dragovič, S. \& Mihailovič, N. (2009). Analysis of Mosses and Topsoils for Detecting Sources of Heavy Metal Pollution: Multivariate and Enrichment Factor Analysis. Environmental Monitoring and Assessment, Vol.157, No.1-4, (2009), pp. 383-390, ISSN 0167-6369

Duffus, J.H. (2002). "Heavy metal"- A Meaningless Term? Pure and Applied Chemistry, Vol. 74, No.5, (2002) pp. 793-807, ISSN 0033-4545

Dymytrova, L. (2009). Epiphytic lichens and bryophytes as indicators of air pollution in Kyiv city (Ukraine). Folia Cryptogamica Estonica, Vol.46, No.1, pp.33-44, ISSN 1406-2070

El-Hassan, T.; Al-Omari, H. Anwar, J. Al-Nasir, F. (2002). Cypress Tree (Cupressus semervirens L.) Bark as an Indicator for Heavy Metal Pollution in the Atmosphere of Amman City, Jordan. Environment International, Vol.28, No.6, (2002), pp. 513-519, ISSN 0160-4120

Fernandez Espinoza, A.J. \& Rossini Oliva, S. (2005). The Composition and Relationships Between Trace Element Levels in Inhalable Atmospheric Particles $\left(\mathrm{PM}_{10}\right)$ and in Leaves of Nerium oleander L. and Lantana camara L. Chemosphere, Vol.62, No.10, (2005), pp. 1665-1672, ISSN 0045-6535

Fernandez, C. C.; Shevock, R. Glazer, N. A. \& Thompson, J. N. (2006). Cryptic Species within the Cosmopolitan Desiccation-Tolerant Moss Grimmia laevigata. Proceedings of the National Academy of Sciences of the United States of America, Vol.103, No.3, (2006), pp. 637 - 642, ISSN 1091-6490

Gailey, F.A.Y. \& Lloyd, O.L. (1993). Spatial and Temporal Patterns of Airborne Metal Pollution: The Value of Low Technology Sampling to an Environmental Epidemiology Study. Science of the Total Environment, Vol.133, No.3, (1993), pp. 201219, ISSN 0048-9697

Galiulin, R.V.; Bashkin, V.N. Galiulina, R.A. \& Kucharski, R. (2002). Airborne Soil Contamination by Heavy Metals in Russia and Poland, and its Remediation. Land Contamination \& Reclamation, Vol.10, No.3, (2002), pp. 179-187, ISSN 0967-0513

Galloway, J.N.; Thornton, J.D. Norton, S.A. Volchok, H.L. \& McClean, H.L. (1982). Trace Metals in Atmospheric Deposition: A Review and Assessment. Atmospheric Environment, Vol.16, No.7, (1982), pp. 1677-1700, ISSN 1352-2310

Garty, J. (1993). Lichens as Biomonitors for Heavy Metal Pollution, In: Plants as Biomonitors Indicators for Heavy Metals in the Terrestrial Environment, B. Markert, (Ed.), 193-263, VCH, ISBN 3527300015, Weinheim

Garty, J. (2000). Environment and Elemental Content of Lichens, In: Trace elements - Their Distribution and Effects in the Environment, B. Markert \& K. Friese (Eds.), 33-86, Elsevier Science, ISBN 0444505326, Amsterdam

Gerdol, R.; Bragazza, L. \& Marchesini, R. (2002). Element Concentrations in the Forest Moss Hylocomium splendens: Variation Associated with Altitude, Net Primary Production and Soil Chemistry. Environmental Pollution, Vol.116, No.1, (2002), pp. 129-135, ISSN 0269-7491

Gjengedal, E. \& Steinnes, E. (1990). Uptake of Metal Ions in Moss from Artificial Precipitation. Environmental Monitoring and Assessment, Vol.14, No.1, (1990), pp. 7787, ISSN 0167-6369

Harmens, H; Norris, D.A. Koerber, G.R. Buse, A. Steinnes, E. \& Rühling, A. (2008a). Temporal Trends $(1990$ - 2000) in the Concentration of Cadmium, Lead and 
Mercury in Mosses across Europe. Environmental Pollution, Vol.151, No.2, (2008), pp. 368-376, ISSN 0269-7491

Harrison, R.M. \& Chirgawi, M.B. (1989). The Assessment of Air and Soil as Contributors of Some Trace Metals to Vegetable Plants. Use of a Filtered Air Growth Cabinet. Science of the Total Environment, Vol.83, No.1-2, (1989), pp. 13-34, ISSN 0048-9697

Kansanen, P. \& Venetvaara, J. (1991). Comparison of Biological Collectors of Airborne Heavy Metals Near Ferrochrome and Steel Works. Water, Air \& Soil Pollution, Vol.60, No.3-4, (1991), pp. 337-359, ISSN 0049-6979

Kovács, M. (1992a). Herbaceous (flowering) Plants. In: Biological indicators in environmental protection, M. Kovács, (Ed.), 76-82, Ellis Horwood Ltd, ISBN 0130849898, New York

Kovács, M. (1992b). Trees as Biological Indicators. In: Biological indicators in environmental protection. M. Kovács, (Ed.), 97-100, Ellis Horwood, ISBN 0130849898, New York.

Long, E.R.; MacDonald, D.D. Smith, S.L. \& Calder, F.D. (1995). Incidence of Adverse Biological Effects within Ranges of Chemical Concentrations in Marine and Estuarine Sediments. Environmental Management, Vol.19, No.1, (1995), pp. 81-97, ISSN 0364-152X

MacNee, W. \& Donaldson, K. (2000). How Can Ultrafine Particles be Responsible for Increased Mortality? Monaldi Archives of Chest Disease, Vol.55, No.2, (2000), pp. 135-139, ISSN 1122-0643

Mankovska, B.; Godzik, B. Badea, O. Shparyk, Y. \& Moravcik, P. (2004). Chemical and Morphological Characteristics of Key Tree Species of the Carpathian Mountains. Environmental Pollution, Vol.130, No.1, (2004), pp. 41-54, ISSN 0269-7491

Manoli, E.; Voutsa, D. \& Samara, C. (2002). Chemical Characterization and Source Identification Apportionment of Fine and Coarse Air Particles in Thessaloniki, Greece. Atmospheric Environment, Vol.36, No.6, (2002), pp. 949-961, ISSN 1352-2310

Markert, B. (1993). Instrumental Analysis of Plants, In: Plants as biomonitors, indicators for heavy metals in terrestrial environment, B. Markert, (Ed), 65-103, VCH, ISBN 1560812729, Weinheim

Markert, B. (2007). Definitions and Principles for Bioindication and Biomonitoring of Trace Metals in the Environment. Journal of Trace Elements in Medicine and Biology, Vol.21, S.1, (2007), pp. 77-82, ISSN 0946-672X

Markert, B.; Oehlmann, J. \& Roth, M. (1997). General Aspects of Heavy Metal Monitoring by Plants and Animals, In: Environmental biomonitoring - exposure, assessment and specimen banking, K.S. Subramanian \& G.V. Iyengar (Eds.), 19-29, ACS Symposium Series, Vol.654, American Chemical Society

Martin, M.H. \& Coughtrey, P.J. (1982). Biological Monitoring of Heavy Metal Pollution, Kluwer Academic, ISBN 978-0853341369, London

Mielke, H.W.; Reagan, P.L. (1988). Soil as an Impact Pathway of Human Lead Exposure. Environmental Health Perspectives, Vol. 106, No. 1, (1988), pp. 217- 29, ISSN 0091-6765

Moore, C.C. (1974). A Modification of the Index of Atmospheric Purity Method for Substrate Differences. The Lichenologists, Vol.6, No.2, (1974), pp. 156-157, ISSN 0024-2829

Morselli, L.; Brusori, B. Passarini, F. Bernardi, E. Francaviglia, R. \& Gatelata, L. (2004). Heavy Metal Monitoring at a Mediterranean Natural Ecosystem of Central Italy Trends in Different Environmental Matrixes. Environment International, Vol.30, No.2, (2004), pp. 173-181, ISSN 0160-4120

Mulgrew, A. \& Williams, P. (2000). Biomonitoring of Air Quality Using Plants, WHO Collaborating Centre for Air Quality Management and Air Pollution Control. (WHO CC) ISSN 0938-9822, Berlin 
Nali, C. \& Lorenzini, G. (2007). Air Quality Survey Carried out by Schoolchildren: an Innovative Tool for Urban Planning. Environmental Monitoring and Assessment, Vol.131, No. 1-3, (2007), pp. 201-210, ISSN 0167-6369

Nash, T.H. (1988). Correlating Fumigation Studies with Field Effects, In: Lichens, Bryophytes and Air Quality, T.H. Nash, \& V. Wirth, (Eds.), Bibliotheca Lichenologica, Vol.30, 201216, J. Cramer, ISBN 3443580092, the University of Michigan

NG, O.H.; Tan, B.C. \& Obbard, J.P. (2006). Lichens as Bioindicator of Atmospheric Heavy Metal Pollution in Singapore. Environmental Monitoring and Assessment, Vol.123, No.1-3, (2006), pp. 63-74, ISSN 0167-6369

Nriagu, J.O. (1980). Global Cycle and Properties of Nickel, In: Nickel in the Environment, J. O. Nriagu, (Ed.), 1-26, John Wiley \& Sons, ISBN 0471058858, New York

Nurnberg, H.W.; Valenta, P. Nguyen, V.D. Godde, M. \& Urano de Carralho, E. (1984). Studies on the Deposition of Acid and Ecotoxic Heavy Metals with Precipates from the Atmosphere. Fresenius Journal of Analytical Chemistry, Vol.317, No.3-4, (1984), pp. 314-323, ISSN 0937-0633

Økland, T.; Økland, R.H. \& Steinnes, E. (1999). Element Concentrations in the Boreal Forest Moss Hylocomium splendens: Variation Related to Gradients in Vegetation and Local Environmental Factors. Plant and Soil, Vol.209, No.1, (1999), pp. 71-83, ISSN 0032-079X

Onianwa, P.C. (2000). Monitoring Atmospheric Metal Pollution: A Review of the Use of Mosses as Indicators. Environmental Monitoring and Assessment, Vol.71, No.1, (2000), pp. 13-50, ISSN 0167-6369

Pacheco, A.M.G. Barros, L.I.C. Freitas, M.C. Reis, M.A. Hipólito, C. \& Oliveira, O.R. (2002). An Evaluation of Olive-tree Bark for the Biological Monitoring of Airborne TraceElements at Ground Level. Environmental Pollution, Vol.120, No.1, (2002), pp. 79-86, ISSN 0269-7491

Pakarinen, P. \& Rinne, R.J.K. (1979). Growth Rates and Heavy Metals Concentrations of Five Moss Species in Paludified Spruce Forest. Lindbergia, Vol.5, No.2, (1979), pp. 77-83, ISSN 0105-0761

Panichev, N. \& Mc Crindle, R.I. (2004). The Application of Bioindicators for the Assessment of Air Pollution. Journal of Environmental Monitoring, Vol.6, No.2, (2004), pp. 121123, ISSN 1464-0325

Poikolainen, J. (2004). Mosses, Epiphytic Lichens and Tree Bark as Biomonitors for Air pollutants - Specifically for Heavy Metals in Regional Surveys. Faculty of Science, Department of Biology, University of Oulu; The Finnish Forest Research Institute, Muhos Research Station, ISBN 951-42-7479-2, Oulu, Finland

Prance, C.T.; Prance, A.E. \& Sandved, K.B. (1993). Bark: The formation, characteristics, and uses of bark around the world, Timber Press, ISBN 978-0881922622, Portland

Puxbaum, H. (1991). Metal Compounds in the Atmosphere, In: Metals and Their Compounds in the Environment: Occurrence, Analysis and Biological Relevance, E. Merian, (Ed.), 257-286, Wiley-VCH, ISBN 352726521X, Weinheim

Rao, D.N. (1984). Response of Bryophytes to Air Pollution, In: Bryophyte Ecology, A.J.E. Smith (Ed), 445-471, Springer, ISBN 0412223406, London

Rasmussen, L. (1978). Element Content of Epiphytic Hypnum cupressiforme Related to Element Content of the Bark of Different Species of Phorophytes. Lindbergia, Vol.4, No.3-4, (1978), pp. 209-218, ISSN 0105-0761 
Reimann, C.; Arnoldussen, A. Boyd, R. Finne, T. R. Nordgulen, Ø. Volden, T. \& Englmaier, P. (2006). The Influence of a City on Element Contents of a Terrestrial Moss (Hylocomium splendens). Science of the Total Environment, Vol.369, No.1-3, (2006), pp. 419-32, ISSN 0048-9697

Richardson, D. H. S. (1981). The Biology of Mosses, Wiley, ISBN 9780470271902, USA

Richardson, D.H.S. \& Nieboer, E. (1981). Lichens and Pollution Monitoring. Endeavour, Vol.5, No.3, (1981), pp. 127-133, ISSN 0160-9327

Rosman, K. J.; Ly, Ch. \& Steinnes, E. (1998). Spatial and Temporal Variation in Isotopic Composition of Atmospheric Lead in Norwegian Moss. Environmental Science $\mathcal{E}$ Technology, Vol.32, No.17, (1998), pp. 2542-2546, ISSN 0013-936X

Ross, H.B. (1990). On the Use of Mosses (Hylocomium splendens and Pleurozium schreberi) for Estimating Atmospheric Trace Metal Deposition. Water, Air, \& Soil Pollution, Vol.50, No.1-2, (1990), pp. 63-76, ISSN 0049-6979

Rossbach, M.; Jayasekera, R. Kniewald, G. \& Hun, N. (1999). Large Scale Air Monitoring: Lichen vs. Air Particulate Matter Analysis. Science of the Total Environment, Vol.232, No.1-2, (1999), pp. 59-66, ISSN 0048-9697

Rossini Oliva, S. \& Mingorance, M.D. (2006). Assessment of Airborne Heavy Metal Pollution by Aboveground Plant Parts, Chemosphere, Vol.65, No.2, (2006), pp. 177-182, ISSN 0045-6535

Seinfeld, J.H. \& Pandis, S.N. (1998). Atmospheric Chemistry and Physics: From Air Pollution to Climate Change, Wiley-Interscience, ISBN 0471178160, New York, USA

Shakya, K.; Chettri, M. K. Sawidis, T. (2008). Impact of Heavy Metals (Copper, Zinc, and Lead) on the Chlorophyll Content of Some Mosses. Archives of Environmental Contamination and Toxicology, Vol.54, No.3, (2008), pp. 412-421, ISSN 0090-4341

Shrivastav, R. (2001). Atmospheric Heavy Metal Pollution (Development of Chronological Records and Geochemical Monitoring). Study in department of chemistry faculty of science, Dayalbagh Educational Institute, Agra, India. Resonance, 62-68. ISSN 09718044

Sloof, J. E. (1995). Lichens as Quantitative Biomonitors for Atmospheric Trace Element Deposition, Using Transplants. Atmospheric Environment, Vol.29, No.1, (1995), pp. ISSN 1352-2310

Smirnioudi, V.; Thomaidis, M.S. Piperaki, E.A. \& Siskos, P.A. (1998). Determination of Trace Metals in Wet and Dust Deposition in Greece. Fresenius Environmental Bulletin, Vol.7, No.1, pp.85-90, ISSN 1018-4619

Smodiš, B. \& Bleise, A. (2000). Biomonitoring of Atmospheric Pollution, Proceeding of International Workshop on, "Internationally harmonised approach to biomonitoring trace element atmospheric deposition", pp. 143-150, ISBN 92-0-100803-1, Portugal, 28 August-3 September, 2000

Spiegel, H. (2002). Trace Element Accumulation in Selected Bioindicators Exposed to Emissions along the Industrial Facilities of Danube Lowland. Turkish Journal of Chemistry, Vol.26, No.6, (2002), pp. 815 - 823, ISSN 1300-0527

Steinnes, E. (1993). Some Aspects of Biomonitoring of Air Pollutants Using Mosses, as Illustrated by the 1976 Norwegian Survey. In: Plants as biomonitors. Indicators for heavy metals in the terrestrial environment, B. Markert, (Ed), 381-394, VHC, ISBN 3527300015, Weinheim 
Steinnes, E.; Johansen, O. Røyset, O. \& Odegard, M. (1993). Comparison of Different MultiElement Techniques for Analysis of Mosses Used as Biomonitors. Environmental Monitoring and Assessment, Vol.25, No.2, (1993), pp. 87-97, ISSN 0167-6369

Szczepaniak, K. \& Biziuk, M. (2003). Aspects of the Biomonitoring Studies Using Mosses and Lichens as Indicators of Metal Pollution. Environmental Research, Vol.93, No.3, (2003), pp. 221-230, ISSN 0013-9351

Taylor, H.J.; Ashmore, M.R. \& Bell, J.N.B. (1990). Air Pollution Injury to Vegetation, IEHO, ISBN 9780900103308, London

Turan, D.; Kocahakimoglu, C. Kavcar, P. Gaygısız, H. Atatanir, L. Turgut, C. \& C.Sofuoglu, S. (2011). The Use of Olive Tree (Olea europaea L.) Leaves as a Bioindicator for Environmental Pollution in the Province of Aydın, Turkey. Environmental Science and Pollution Research, Vol.18, No.3, (2011), pp. 355-364, ISSN 0944-1344

W.H.O. (World Health Organization). (2002). Reducing Risks, Promoting Healthy Life. 1211 Geneva 27, Switzerland

Wannaz, W.D.; Carreras, H.B. Pérez, C.A. \& Pignata, M.L. (2006). Assessment of Heavy Metal Accumulation in Two Species of Tillandsia in Relation to Atmospheric Emission Sources in Argentina. Science of the Total Environment, Vol.361, No.1-3, (2006), pp. 267-278, ISSN 0048-9697

Ward, N.I.; Reeves, R.D. \& Brooks, R.R. (1975). Lead in Soils and Vegetation along a New Zealand State Highway with Low Traffic Volume. Environmental Pollution, Vol.9, No.4, (1975), pp. 243-251, ISSN 0269-7491

Watmough, S.A. \& Hutchinson, T.C. (2003). Uptake of 207Pb and 111Cd through Bark of Mature Sugar Maple,White Ash and White Pine: a Field Experiment. Environmental Pollution, Vol.121, No.1, (2003), pp. 39-48, ISSN 0269-7491

Wittig, R. (1993). General Aspects of Biomonitoring Heavy Metals by Plants. In: Plants as biomonitors - Indicators for heavy metals in the terrestrial environment, B. Markert, (Ed), pp.3-27, VHC, ISBN 3527300015, Weinheim

Wolterbeek, B. (2002). Biomonitoring of Trace Element Air Pollution: Principles, Possibilities and Perspectives. Environmental Pollution, Vol.120, No.1, (2002), pp. 11-21, ISSN 0269-7491

Wolterbeek, H.Th. \& Bode, P. (1999). Strategies in Sampling and Sample Handling in the Context of Large-scale Plant Biomonitoring Surveys of Trace Element Air Pollution. Science of the Total Environment, Vol.176, No.1-3, (1999), pp. 33-43, ISSN 0048-9697

Wolterbeek, H.Th. \& Verburg, T.G. (2002). Judging Survey Quality: Local Variances. Environtal Monitoring and Assessment, Vol.73, No.1, pp. 7-16, ISSN 0167-6369

Wolterbeek, H.Th.; Garty, J. Reis, M.A. \& Freitas, M.C. (2003). Biomonitors in Use: Lichens and Metal Air Pollution, In: Bioindicators and biomonitors, B.A. Markert, A.M. Breure, \& H.G. Zechmeister, 377-419, Elsevier, ISBN 0080441777, Oxford

Zechmeister, H.G.; \& Hohenwallner, D. (2006). A Comparison of Biomonitoring Methods for the Estimation of Atmospheric Pollutants in an Industrial Town in Austria. Environmental Monitoring and Assessment, Vol.117, No.1-3, (2006), pp. 245-259, ISSN 0167-6369

Zoller, W. H.; Gladney, E. S. \& Duce R. A. (1974). Atmospheric Concentrations and Sources of Trace Metals at the South Pole. Science, Vol.183, No.4121, (1974), pp. 198-200, ISSN 0036-8075 


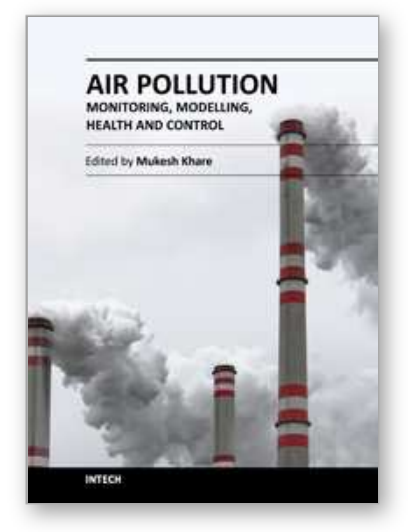

\author{
Air Pollution - Monitoring, Modelling, Health and Control \\ Edited by Dr. Mukesh Khare
}

ISBN 978-953-51-0381-3

Hard cover, 254 pages

Publisher InTech

Published online 21, March, 2012

Published in print edition March, 2012

Air pollution has always been a trans-boundary environmental problem and a matter of global concern for past many years. High concentrations of air pollutants due to numerous anthropogenic activities influence the air quality. There are many books on this subject, but the one in front of you will probably help in filling the gaps existing in the area of air quality monitoring, modelling, exposure, health and control, and can be of great help to graduate students professionals and researchers. The book is divided in two volumes dealing with various monitoring techniques of air pollutants, their predictions and control. It also contains case studies describing the exposure and health implications of air pollutants on living biota in different countries across the globe.

\title{
How to reference
}

In order to correctly reference this scholarly work, feel free to copy and paste the following:

Mehran Hoodaji, Mitra Ataabadi and Payam Najafi (2012). Biomonitoring of Airborne Heavy Metal Contamination, Air Pollution - Monitoring, Modelling, Health and Control, Dr. Mukesh Khare (Ed.), ISBN: 978953-51-0381-3, InTech, Available from: http://www.intechopen.com/books/air-pollution-monitoring-modellinghealth-and-control/biomonitoring-of-airborne-heavy-metal-contamination

\section{INTECH}

open science | open minds

\section{InTech Europe}

University Campus STeP Ri Slavka Krautzeka 83/A 51000 Rijeka, Croatia Phone: +385 (51) 770447

Fax: +385 (51) 686166 www.intechopen.com

\section{InTech China}

Unit 405, Office Block, Hotel Equatorial Shanghai No.65, Yan An Road (West), Shanghai, 200040, China 中国上海市延安西路65号上海国际贵都大饭店办公楼405单元 Phone: +86-21-62489820

Fax: $+86-21-62489821$ 
(C) 2012 The Author(s). Licensee IntechOpen. This is an open access article distributed under the terms of the Creative Commons Attribution 3.0 License, which permits unrestricted use, distribution, and reproduction in any medium, provided the original work is properly cited. 